Sport Science: Jurnal Sain Olahraga dan Pendidikan Jasmani ISSN 114-562X (Cetak), ISSN XXXX-XXXX(Online)

http://sportscience.ppj.unp.ac.id/index.php/jss/index

\title{
Hubungan Keseimbangan Dan Kelincahan Dengan Hasil Dribbling Pemain Sepakbola Sekolah Menengah Atas Negeri 9 Padang
}

\author{
Wahyudi $^{1}$, Zainul Johor ${ }^{2}$ \\ ${ }^{12}$ Fakultas Ilmu Keolahragaan, Universitas Negeri Padang, Indonesia. \\ E-mail: wahyudi@yahoo.com ${ }^{1}$, zainul1956@,fik.unp.ac.id ${ }^{2}$
}

\begin{abstract}
Abstrak
Masalah dalam penelitian ini berawal dari observasi dan wawancara peneliti dengan guru mata pelajaran penjasorkes yang sekaligus menjadi pelatih tim sepakbola SMA Negeri 9 Padang. Setelah peneliti mengikuti latihan dan uji coba tanding SMA Negeri 9 Padang, terlihat masih rendahnya keterampilan siswa dalam mendribbling atau mengiring bola. Di dalam mendribling bola, bola tersebut lebih mudah dirampas oleh lawan. Hal ini diduga penyebabnya adalah keseimbangan dan kelincahan yang belum begitu baik. Tujuan penelitian ini adalah untuk mengetahui hubungan keseimbangan dan kelincahan dengan hasil dribbling pemain sepakbola SMA Negeri 9 Padang.

Jenis penelitian ini korelasional yaitu untuk melihat hubungan antara keseimbangan dan kelincahan dengan hasil dribbling pemain sepakbola SMA Negeri 9 Padang. Populasi dalam penelitian ini pemain sepakbola SMA Negeri 9 Padang yang berjumlah 20 orang. Dengan menggunakan teknik total sampling dimana semua populasi dijadikan sampel, untuk data penelitian digunakan tes Stork Stand, Shuttle run dan dribbling bola dengan zig-zag. Data penelitian ini di analisis dengan menggunakan rumus korelasi product moment, sebelum uji hipotesis terlebih dahulu dilakukan uji normalitas menggunakan analisis regresi variabel.

Hasil penelitian pada hipotesis pertama terdapat hubungan signifikan antara keseimbangan dengan hasil dribbling bernilai rhit $-0.451>$ r-tab 0.444 , berarti hubungan keseimbangan kuat dan tidak searah (negatif). Hipotesis kedua terdapat hubungan yang signifikan (berarti) antara kelincahan dengan hasil dribbling bernilai rhit $0.477>$ r-tab 0.444, berarti hubungan kelincahan kuat dan searah (positif). Dan hipotesis ketigaTerdapat hubungan yang kuat dan searah tetapi tidak signifikan (berarti) antara keseimbangan dan kelincahan secara bersama sama dengan hasil dribbling bernilai rhitung $0.551>$ r-tab 0.444 Dibuktikan dengan nilai Fhit 3.068 > Ftab 3.59. Dengan demikian hipotesis kerja yang diajukan $(\mathrm{Ha})$ tidak dapat diterima. Dengan demikian berarti hubungan keseimbangan dan kelincahan secara bersama-sama dengan hasil dribbling memang terdapat hubungan yang kuat dan searah tetapi tidak signifikan (berarti).
\end{abstract}

Kata Kunci: Keseimbangan, kelincahan, hasil dribbling

\begin{abstract}
The problem in this study originated from the observation and interview of researchers with a teacher of the penjasorkes subject as well as the trainer of the 9 Padang public high school football team. After the researchers participated in the training and trial of high school Negeri 9 Padang, there was still low student skills in dribbling or taking a ball. In the mendribling of the ball, the ball is more easily robped by the opponent. It is suspected that the cause is balance and agility is not so good. The purpose of this research is to know the relationship of balance and agility with the results of the dribbling of senior high school football player 9 Padang.

This type of correlational research is to see the relationship between balance and agility with the results of dribbling of high school football player 9 Padang. The population in this study was the 9 Padang high school football player which amounted to 20 people. By using the total sampling
\end{abstract}


technique where all the populations are made samples, for the research data used Stork Stand tests, Shuttle runs and ball dribbling with zig-zag. This research Data is in analysis by using the correlation formula of product moment, before the hypothesized test was carried out test normality using variable regression analysis.

The results of research on the first hypothesis there is a significant link between the balance with the results of dribbling worth Rhit-0451 > R-Tab 0444, meaning the relationship of balance is strong and not direct (negative). The second hypothesis is that a significant relationship (meaning) between agility and dribbling results is worth Rhit $0477>$ R-Tab 0444, meaning strong and direct agility relationship (positive). And hypothesized Inequation of strong and direct relationships but not significant (meaning) between balance and agility together with the same dribbling result worth Rcount $0551>R$-Tab 0444 evidenced by the value of Fhit 3,068 > Ftab 3.59. Thus the hypothesis of the proposed work (HA) is unacceptable. Thus, it means that the relationship of balance and agility together with the result of dribbling is a strong and direct relationship but not significant (meaning).

\section{Keywords: Balance, Agility, Dribbling results}

\section{PENDAHULUAN}

Untuk mencapai suatu prestasi dalam olahraga diperlukan pengembangan dan pembinaan olahraga tersebut, dalam pelaksanaannya diperlukan pengawasan dan pengelolaan pelatihan yang serius untuk tujuan mencapai prestasi dalam olahraga. Penjelasan ini dipertegas oleh (Rosmawati, 2016) "olahraga dapat memberikan sumbangan yang sangat berarti dan berharga bagi manusia secara menyeluruh, karena yang berkembang bukan hanya aspek kelenturan dan kebugaran jasmani saja, namun juga aspek lain yang sangat penting dari sosok manusia seutuhnya yaitu perkembangan pengetahuan penalaran, perkembangan intelegensi emosional dan sifat-sifat lainya yang membuat karakter seseorang menjadi tangguh, sportif dan disiplin". Pengembangan olahraga prestasi bisa dimulai dari sekolah, melalui mata pelajaran pendidikan jasmani, olahraga dan kesehatan(PENJASORKES) serta kegiatan ekstrakurikuler yang diadakan disekolah-sekolah.

Maka dengan pembinaan yang terstruktur dengan baik, sehingga pengembangan olahraga prestasi disekolah dapat berjalan sebagaimana mestinya sehingga dapat melahirkan atlet-atlet yang berprestasi disekolah. Penjelasan ini sesuai dengan pendapat (Asnaldi, 2016) "kegiatan olahraga yang ingin dikembangkan harus dilakukan secara sistematis, terukur, dan terarah". Selanjutnya dalam pengembangannya dibutuhkan perhatian sekolah, khususnya guru penjasorkes dan juga sokongan dari pemerintah. Salah satu upaya yang dilakukan pemerintah dalam pembinaan dan pengembangan olahraga prestasi disekolah dengan disediakannya diklat-diklat bagi atlet berprestasi yang berasal dari sekolah, serta menyelenggarakan pertandingan-pertandingan yang melibatkan sekolah seperti, Liga Pendidikan Indonesia(LPI), Pekan Olahraga Pelajar Daerah(POPDA), Pekan Olahraga Pelajar Nasional(POPNAS), Pekan Olahraga Usia Dini (PORDINI), dan lain sebagainya.

Dari sekian banyak cabang olahraga prestasi, yang perlu mendapat perhatian untuk dibina disekolah adalah sepakbola. Sepakbola merupakan cabang olahraga yang sangat digemari masyarakat dunia pada umumnya dan Indonesia pada khususnya. Senanda dengan pendapat (Velnika Elmanisar, Yulifri, 2017) "Olahraga sepakbola merupakan salah satu cabang olahraga yang sangat populer dan digemari di seluruh dunia, mulai dari rakyat kecil hingga masyarakat kelas atas mengenal dan menggemari olahraga sepak bola, oleh sebab itu olahraga sepakbola sangat banyak mendapat sorotan dari masyarakat dalam respon yang positif, baik dari semua kalangan masyarakat maupun pemerintah". Sedangakan sepakbola merupakan permainan yang mempunyai gerakan kompleks yaitu gabungan dari jalan, lari dan lompat serta unsur kekuatan, kecepatan, ketepatan, kelentukan dan lain-lain. Sepakbola merupakan permainan tim, oleh karena itu kerja sama tim merupakan kebutuhan permainan sepakbola yang harus dipenuhi oleh setiap kesebelasan yang menginginkan kemenangan. 
Sport Science: Jurnal Sain Olahraga dan Pendidikan Jasmani ISSN 114-562X (Cetak), ISSN XXXX-XXXX(Online)

http://sportscience.ppj.unp.ac.id/index.php/jss/index

Kemenangan dalam permainan sepak bola hanya akan diraih melaui kerja sama tim tersebut. Kemenangan tidak dapat diraih secara perseorangan dalam permainan tim, di samping itu setiap individu atau pemain harus memiliki kondisi fisik yang bagus, teknik dasar yang baik dan mental bertanding yang baik pula.

Dalam permainan sepakbola kemenangan hanya dapat diraih dengan membuat gol ke gawang lawan sebanyak-banyaknya dan mencegah jangan sampai lawan berbuat yang sama terhadap gawang sendiri. Hal ini mengandung pengertian bahwa seorang pemain sepakbola harus memiliki dan menguasai teknik bermain yang baik.

Penguasaan teknik dasar bermain sepakbola perlu ditingkatkan pemain itu sendiri. Pelaksanaan teknik dalam permainan sepakbola sangat tergantung kepada kematangan atau penguasaan teknik dari setiap individu dalam suatu kesebelasan. Penampilan teknik pemain sepakbola sangat tergantung kepada daya pikir dalam mengambil keputusan atau inisiatif dan ditunjang oleh kondisi fisik yang baik serta mental. Sesuai dengan pendapat (Velnika Elmanisar, Yulifri, 2017) "Dalam permainan sepakbola teknik dribbling merupakan teknik dasar yang harus dimiliki oleh seorang pemain sepakbola" Dengan demikian penguasaan teknik dribbling atau menggiring bola tidaklah mudah dilakukan, cukup banyak faktor-faktor dan prinsip-prinsip dalam melakukan teknik menggiring bola dan ini harus diketahui oleh pemain sepakbola untuk dapat melakukan dribbling dengan cepat dan tepat.

Untuk melakukan dribbling bola secara cepat dan tepat dibutuhkan keseimbangan yang baik. Dapat disimpulkan bahwa keseimbangan sangat diperlukan dalam mempertahankan kondisi tubuh, baik dalam keadaan statis (kemampuan mempertahankan keadaan seimbang dalam keadaan diam), maupun dinamis (kemampuan mempertahankan seimbang dalam keadaan bergerak). Begitu juga dalam melakuan dribbling agar kondisi tubuh tetap terkontrol dengan baik. Dapat disimpulkan bahwa keseimbangan sangat diperlukan dalam mempertahankan kondisi tubuh, baik dalam keadaan statis (kemampuan mempertahankan keadaan seimbang dalam keadaan diam), maupun dinamis (kemampuan mempertahankan seimbang dalam keadaan bergerak.

Dari uraian di atas, jelaslah bahwa seorang pemain sepakbola SMA Negeri 9 Padang untuk dapat memiliki keterampilan dribbling bola dengan baik, diantaranya faktor yang mempengaruhinya adalah keseimbangan dan kelincahan. Menurut (Asnaldi, 2019) "Unsur-unsur dasar kemampuan gerak yang dinamis dan mudah dikerjakan adalah daya ledak lengan dan tungkai, kecepatan, kelincahan, dan koordinas". Sedangakan pada saat mendribling atau mengiring bola seorang pemain harus memiliki kemampuan untuk merubah arah gerakan secara cepat tanpa kehilangan keseimbangan.

Disamping itu ada faktor lain yang dapat mempengaruhi seorang pemain untuk dapat menguasai teknik dribbling atau mengiring bola adalah kelincahan, menurut Harsono (1988:172) berpendapat bahwa kelincahan adalah "Seseorang yang mempunyai kemampuan untuk merubah arah dan posisi tubuh dengan cepat dan tepat pada waktu sedang bergerak tanpa kehilangan keseimbangan dan kesadaran akan posisi tubuhnya".

Hal ini sangat berkaitan dengan pelaksanaan dribbling yang menuntut kelincahan dalam melakukan dribbling dan pada saat melewati lawan. Begitu juga halnya dengan pemain sepakbola SMA Negeri 9 Padang dalam melakukan dribbling bola. Berdasarkan observasi dan wawancara peneliti dengan guru mata pelajaran penjasorkes yang sekaligus menjadi pelatih tim sepakbola di SMA Negeri 9 Padang, bahwa sekolah tesebut memiliki tim sepakbola yang sering mengikuti pertandingan sepakbola dan sering juga mendapatkan juara.

Seperti Liga pelajar tingkat SLTA se kota Padang tahun 1990 mendapatkan juara 3, Liga Muhammaddiyah tahun 2005 tingkat SLTA se SUMBAR (dikdasmen PDAM kota Padang) mendapatkan juara 1, football championship DPD.KNP tingkat Kodya Padang mendapat juara 1, dan masih banyak kejuaraan sepakbola yang diikuti oleh SMA Negeri 9 padang, tetapi beberapa turnamen yang diikuti oleh SMA Negeri 9 Padang belum menghasilkan prestasi yang membanggakan, terakhir 
di pertandingan Liga Pendidikan Indonesia(LPI) tahun 2011 yang diikuti oleh SMA Negeri 9 Padang yang hanya sampai di babak 8 besar saja.

Melihat kenyataan di lapangan, setelah peneliti yang mengikuti latihan dan uji coba tanding SMA Negeri 9 Padang, terlihat masih rendahnya keterampilan siswa dalam mendribbling atau mengiring bola. Maka dari itu, peneliti merasa tertarik dan ingin melakukan suatu penelitian tentang penyebab belum begitu baiknya keterampilan mendribbling atau mengiring bola pemain sepak bola SMA Negeri 9 Padang tersebut. Yang peneliti pradugai disebabkan karena keseimbangan dan kelincahan yang mungkin ada hubungan dengan hasil dribbling atau mengiring bola.

\section{METODE}

Jenis penelitian ini adalah korelasional yang ingin melihat hubungan antara variabel bebas dan terikat. Sujana (1992:63) mengemukakan bahwa: "penelitian korelasi merupakan penelitian untuk mengetahui ada tidaknya hubungan antara dua variabel, besar tidaknya hubungan dua variabel tersebut dinyatakan dalam bentuk koefisien korelasi”. Adapun variabel bebas dalam penelitian ini adalah keseimbangan dan kelincahan sedangkan yang menjadi variabel terikatnya adalah hasil dribbling pemain sepakbola SMA Negeri 9 Padang.

Penelitian ini akan dilaksanakan di lapangan sepakbola UNAND Padang, berdasarkan Arikunto (1993:115) yang menyatakan bahwa: "Populasi adalah keseluruhan subjek penelitian". Dengan demikian populasi dalam penelitian ini adalah pemain sepakbola SMA Negeri 9 Padang yang berjumlah 20 orang. Berdasarkan populasi penelitia diatas yakni pemain sepakbola SMA Negeri 9 Padang yang berjumlah 20 orang, yang secara fisiologis sudah adanya perkembangan fisik motorik pemain.Menurut Sugiono (2006:118) sampel adalah "bagian dari jumlah dan karekteristik yang dimiliki oleh populasi tersebut". Mengingat populasinya hanya sedikit, maka ditetapkan sampel secara total sampling, dimana semua populasi dijadikan sampel.

Jenis data yang diperlukan dalam penelitian ini adalah data primer dan data sekunder. Data primer yaitu data yang langsung dikumpulkan oleh peneliti melalui tes dan pengukuran variabel keseimbangan dan kelincahan dan hasil dribbling. Sedangkan data sekunder yaitu data tentang pemain sepakbola, yang diperolehdari Guru Penjas atau Pelatih di SMA Negeri 9 Padang.

\section{Teknik dan Alat Pengumpulan Data}

\section{Keseimbangan}

Tes keseimbangan dengan menggunakan tes Stork Stand, penilaian: skor di peroleh yaitu waktu terlama dari hitungan detik, antara tumit di naik kan sampai keseimbangan hilang. Tes dilakukan dalam 3 kali pengulangan, waktu terlama yang diambil.

Tabel 1. Norma Keseimbangan

\begin{tabular}{ccc}
\hline NO & Norma & T-Skor \\
\hline 1 & BaikSekali & $>60$ Detik \\
2 & Baik & $48-60$ Detik \\
3 & Sedang & $21-47$ Detik \\
4 & Kurang & $1-20$ Detik \\
5 & KurangSekali & $<1$ Detik \\
\hline \multicolumn{3}{c}{ Sumber :Sudjadji }
\end{tabular}

\section{Kelincahan}

Untuk mengukur kelincahan dilakukan dengan shuttle-run test 6 × 10 meter

Tabel 2. Norma Kelincahan

\begin{tabular}{ccc}
\hline NO & Kelas Interval & Kategori \\
\hline 1 & $<15.5$ detik & Sempurna \\
2 & $15.6-16.0$ detik & Baiksekali \\
\hline
\end{tabular}




\section{Dribbling Bola}

\begin{tabular}{ccc}
\hline 3 & $16.1-16.6$ detik & Baik \\
4 & $16.7-17.1$ detik & Sedang \\
5 & $17.2-17.7$ detik & Kurang \\
6 & $17.8>$ detik & Kurangsekali \\
\hline \multicolumn{4}{c}{ Sumber: Luthan 1999}
\end{tabular}

Untuk mengukur keterampilan dribbling bola diambi berdasarkan pada tes kecakapan untuk mahasiswa FIK UNP Arsil (2006:22) yang menyatakan tujuan: Mengukur keterampilan, Pelaksanaan: Testee berdiri di belakang garis start atau cones pertama, setelah ada abaaba"ya". Testee melewati cones dengan zig-zag yaitu sekali kiri dan satu kanan sampai cones kesepuluh, langsung balik kearah cones start dengan cara yang sama secepat mungkin. Testee memperoleh kesempatan dua kali pengulangan, waktu yang di ambil adalah waktu yang terbaik.

Tabel 3. Norma dribling

\begin{tabular}{ccc}
\hline NO & Kelas Interval & Kategori \\
\hline 1 & $<15.5$ detik & Sempurna \\
2 & $15.6-16.6$ detik & Baiksekali \\
3 & $16.7-17.7$ detik & Baik \\
4 & $17.8-18.8$ detik & Sedang \\
5 & $18.9-19.9$ detik & Kurang \\
\hline
\end{tabular}

\section{TeknikAnalisis Data}

Sumber: Arsil (2006:22)

Teknik analisis data yang digunakan berkenaan dengan perhitungan untuk menjawab rumusan masalah dan pengujian hipotesis yang diajukan. Bentuk hipotesis mana yang diajukan, akan menentukan teknik statistik mana yang digunakan. Teknik analisis data di dalam penelitian ini di gunakan teknik analisis korelasi pearson product moment (PPM) yang bertujuan untuk mengetahui derajad hubungan antara variabel bebas (independent) dengan variabel terikat (dependent). Teknik analisis korelasi pearson product moment (PPM) yang di gunakan yaitu menurut Riduwan (2005:138).

Analisis korelasi ganda berfungsi untuk mencari besarnya pengaruh atau hubungan antara dua variabel bebas $(\mathrm{X})$ atau secara simultan (bersama-sama) dengan variabel terikat (Y). Rumus korelasi ganda menurut Riduwan (2005:141). Selanjutnya untuk mengetahui signifikan sikorelasi ganda, dicari $\mathrm{F}$ hitung kemudian dibandingkan dengan Ftabel. Dan analisis regeresi digunakan untuk memprediksikan seberapa jauh perubahan nilai variabel dependen, bila nilai variabel independen di dirubah-rubah atau dinaik-turunkan. Peningkatan ataupun penurunan variabel dependen yang didasarkan pada perubahan variabel independen. Bila $(+)$ arah garis naik, dan bila (-) maka arah garis turun. $\mathrm{X}=$ Subyek pada variabel independen yang mempunyai nilai tertentu.

\section{HASIL DAN PEMBAHASAN \\ Hasil Penelitian}

Seperti yang dijelaskan dalam bab sebelumnya bahwa variabel dalam penelitian ini adalah keseimbangan, kelincahan dan hasil dribbling pemain sepakbola SMA Negeri 9 Padang. Pengolahan data penelitian data dilihat dalam tabel dibawah ini :

Tabel 4. Deskripsi Data Penelitian

\begin{tabular}{cccccc}
\hline Variabel & $\mathbf{N}$ & $\bar{X}$ & Std.dev & Min & Mak \\
\hline Keseimbangan & 20 & 51.31 & 24.43 & 16.08 & 109.23 \\
Kelincahan & 20 & 16.98 & 0.84 & 15.66 & 18.62 \\
Hasil Dribbling & 20 & 16.86 & 1.23 & 13.98 & 19.06 \\
\hline
\end{tabular}


Dari tabel diatas terlihat bahawa banyak sampelnya adalah 20 oang siswa SMA Negeri 9 Padang rata-rata nilai keseimbangan memperoleh 51.31, kelincahan memperoleh 16.98, dan hasil dribbling yang diperoleh 16.86. Dalam pelaksanaan penelitian tersebut maka peneliti akan mejelaskan secara deskriptif dirincikan sebagai berikut :

\section{Keseimbangan}

Analisis deskriptif keseimbangan responden penelitian, diperoleh rata-rata hitung (mean) $=51.31$, standar deviasi $=24.43$, nilai minimum $=16.08$ dan maksimum $=109.23$. Jelasnya dapat disajikan pada tabel berikut :

Tabel 5. Distribusi Frekuensi Data Keseimbangan

\begin{tabular}{ccc}
\hline $\boldsymbol{K}-\boldsymbol{I}$ & $\boldsymbol{F a}$ & $\boldsymbol{F r}$ \\
\hline $16.08-34.71$ & 7 & 35 \\
$34.72-53.34$ & 3 & 15 \\
$53.35-71.97$ & 6 & 30 \\
$71.98-90.60$ & 3 & 15 \\
$90.61-109.23$ & 1 & 5 \\
$\Sigma$ & 20 & 100 \\
\hline
\end{tabular}

Berdasarkan table 5 terlihat bahwa keseimbangan dari 20 orang sampel pemain sepakbola SMA Negeri 9 Padang sebanyak 7 orang responden berada dalam kelas interval 16.08-34.71, 3 orang responden berada dalam interval 34.72-53.34, 6 orang responden berada dalam interval 53.35-71.97, 3 orang responden berada dalam interval 71.98-90.60 dan 1 orang responden berada dalam interval 90.61-109.23.

\section{Kelincahan}

Berdasarkan penelitian pada siswa SMA Negeri 9 Padang. Analisis deskriptif kelincahan responden penelitian, diperoleh rerata hitung $($ mean $)=16.98$, standar deviasi $=0.84$, nilai minimum $=$ 15.66 dan maksimum $=18.62$. Jelasnya dapat disajikan pada tabel berikut :

Tabel 6. Distribusi Frekuensi Data Kelincahan

\begin{tabular}{ccc}
\hline $\boldsymbol{K}-\boldsymbol{I}$ & $\boldsymbol{F a}$ & $\boldsymbol{F r}$ \\
\hline $15.66-16.25$ & 5 & 25 \\
$16.26-16.84$ & 3 & 15 \\
$16.85-17.43$ & 7 & 35 \\
$17.44-18.02$ & 3 & 15 \\
$18.03-18.62$ & 2 & 10 \\
$\sum$ & 20 & 100 \\
\hline
\end{tabular}

Berdasarkan tabel 6 di atas terlihat kelincahan dari 20 orang sampel pemain sepakbola SMA Negeri 9 Padang sebanyak 5 orang responden berada dalam kelas interval 15.66-16.25, 3 orang responden berada dalam interval 16.26-16.84, 7 orang responden berada dalam interval 16.8517.43, 3 orang responden berada dalam interval 17.44-18.02 dan 2 orang responden berada dalam interval 18.03-18.62.

\section{Hasil Dribbling}

Analisis deskriptif hasil dribbling responden penelitian, diperoleh rerata hitung $($ mean $)=16.86$, standar deviasi $=1.23$, nilai minimum $=13.98$ dan maksimum $=19.06$. Jelasnya dapat disajikan pada tabel berikut :

Tabel 7. Distribusi Frekuensi Data Hasil Dribbling

\begin{tabular}{ccc}
\hline $\boldsymbol{K}-\boldsymbol{I}$ & $\boldsymbol{F a}$ & $\boldsymbol{F r}$ \\
\hline $13.98-15.00$ & 3 & 15 \\
$15.01-16.02$ & 2 & 10 \\
$16.03-17.04$ & 3 & 15 \\
$17.05-18.06$ & 10 & 50 \\
\hline
\end{tabular}




\begin{tabular}{ccc}
\hline $18.07-19.08$ & 2 & 10 \\
$\sum$ & 20 & 100 \\
\hline
\end{tabular}

Berdasarkan tabel 7 terlihat hasil dribbling dari 20 orang sampel pemain sepakbola SMA Negeri 9 Padang sebanyak 3 orang responden berada dalam kelas interval 13.98-15.00, 2 orang responden berada dalam interval 15.01-16.02, 3 orang responden berada dalam interval 16.03-17.04, 10 orang responden berada dalam interval 17.05-18.06 dan 2 orang responden berada dalam interval 18.0719.08 .

\section{Analisis dan Hasil Penelitian}

Pengolahan dan analisis dilakukan terhadap hubungan serta kontribusi keseimbangan $\left(X_{1}\right)$, kelincahan $\left(\mathrm{X}_{2}\right)$ dengan hasil dribbling $(\mathrm{Y})$. Uji statistik yang digunakan adalah analisis korelasi product moment yang dilanjutkan uji regresi pada taraf signifikansi $0.05 \alpha$. Hasil analisis menunjukkan bahwa keseimbangan, kelincahan memiliki hubungan yang signifikan serta memberikan kontribusi yang berarti terhadap hasil dribbling. Jelasnya akan disajikan sebagai berikut :

\section{Terdapat Hubungan Signifikan Keseimbangan $\left(X_{1}\right)$ dengan Hasil Dribbling $(Y)$.}

Hasil analisis menunjukan bahwa keseimbangan $\left(\mathrm{X}_{1}\right)$, memiliki hubungan yang signifikan serta memberikan kontribusi yang berarti terhadap hasil dribbling $(\mathrm{Y}), \mathrm{P}=0.046<0.05 \alpha$. Pada tabel correlation analisis, data penelitian dapat dibaca bahwa hubungan (korelasi) keseimbangan dengan hasil dribbling bernilai $-0.451>r_{\text {-tab }} 0.444$, berarti hubungan keseimbangan kuat dan tidak searah (negatif).

Berdasarkan kekuatan hubungan ke dua variabel, maka nilai persamaan regresi dapat digambarkan sebagai berikut $Y=18.029$ - $0.022 X_{l}$, dengan $F_{\text {hit }} 4.604>F_{\text {tab }} 4.41$ dan $T_{\text {hit }} 2.146>T_{\text {tab }}$ 1.743. Dengan demikian hipotesis kerja yang diajukan (Ha) dapat diterima. Selanjutnya diperoleh nilai determinasi hasil analisis data $\left(r^{2}\right)$ sebesar 0.204. Artinya bahwa keseimbangan sebagai independent variabel dapat berkonstribusi sebesar $20.4 \%$ terhadap dependent variabel yaitu hasil dribbling. Sedangkan sisanya diterangkan oleh variabel lain. Hasil analisis dapat dilihat pada lampiran.

\section{Terdapat Hubungan Signifikan Kelincahan $\left(\mathrm{X}_{2}\right)$ dengan Hasil Dribbling $(\mathbf{Y})$.}

Hasil analisis menunjukan bahwa kelincahan $\left(\mathrm{X}_{2}\right)$, memiliki hubungan yang signifikan serta memberikan kontribusi yang berarti terhadap hasil dribbling $(\mathrm{Y}), \mathrm{P}=0.033<0.05 \alpha$. Pada tabel correlation analisis, data penelitian dapat dibaca bahwa hubungan (korelasi) kelincahan dengan hasil dribbling bernilai $0.477>r_{\text {-tab }} 0.444$, berarti hubungan kelincahan kuat dan searah (positif). Berdasarkan kekuatan hubungan ke dua variabel, maka nilai persamaan regresi dapat digambarkan sebagai berikut $Y=5.027+0.697 X_{2}$, dengan $F_{\text {hit }} 5.312>F_{\text {tab }} 4.41$ dan $T_{\text {hit }} 2.305>T_{\text {tab }} 1.743$.

Dengan demikian hipotesis kerja yang diajukan $(\mathrm{Ha})$ dapat diterima. Selanjutnya diperoleh nilai determinasi hasil analisis data $\left(r^{2}\right)$ sebesar 0.228. Artinya bahwa kelincahan sebagai independent variabel dapat berkonstribusi sebesar $22.8 \%$ terhadap dependent variabel yaitu hasil dribbling. Sedangkan sisanya diterangkan oleh variabel lain. Hasil analisis dapat dilihat pada lampiran.

\section{Terdapat Hubungan Signifikan Keseimbangan $\left(X_{1}\right)$ dan Kelincahan $\left(X_{2}\right)$ Secara Bersama Dengan Hasil Dribbling (Y)}

Hasil analisis secara bersama $\left(\mathrm{X}_{1,2}\right)$ menunjukan bahwa, keseimbangan secara bersama dengan kelincahan tidak memiliki hubungan yang signifikan serta tidak memberikan kontribusi yang berarti terhadap hasil dribbling $(\mathrm{Y}), P=0.073>0.05 \alpha$. Pada tabel model summary analisis, data penelitian dapat dibaca bahwa hubungan (korelasi) keseimbangan, kelincahan dengan hasil dribbling bernilai 0.551 $>r_{\text {-tab }} 0.444$.

Berarti secara bersama hubungan keseimbangan, kelincahan dan hasil dribbling kuat dan searah tetapi tidak berarti (signifikan). Dibuktikan dengan nilai $F_{h i t} 3.068>F_{t a b} 3.59$. Dengan demikian hipotesis kerja yang diajukan (Ha) tidak dapat diterima. Hasil analisis dapat dilihat pada lampiran. 


\section{Pembahasan}

Hipotesis pertama yang diajukan bahwa terdapatnya hubungan yang signifikan (berarti) antara keseimbangan dengan hasil dribbling pemain sepak bola SMA Negeri 9 Padang bernilai rhitung $0.451>$ r-tab 0.444 , berarti hubungan keseimbangan kuat dan tidak searah (negatif). Artinya hipotesis yang diajukan di dalam penelitian ini diterima kebenarannya secara empiris. Selanjutnya diperoleh nilai determinasi hasil analisis data (r2) sebesar 0.204. Artinya bahwa keseimbangan sebagai independent variabel dapat berkonstribusi sebesar $20.4 \%$ terhadap dependent variabel yaitu hasil dribbling. Sedangkan sisanya diterangkan oleh variabel lain.

Dari uraian di atas, jelaslah bahwa keseimbangan mempunyai hubungan dengan dribbling atau mengiring bola. Jika pemain sepakbola SMA N 9 Padang yang memiliki keseimbangan pasti akan memiliki hasil dribbling yang baik. Keseimbangan di perlukan agar berhasil dalam melaksanakan keterampilan gerak dan untuk mempertahankan posisi atau sikap tubuh, kemampuan tersebut merupakan salah satu sifat dasar dalam olahraga dinamis yang sewaktu-waktu dapat berubah kedudukan dalam melaksanakan suatu gerakan.

Dapat dilihat dalam suatu pertandingan sepakbola, di saat mendribling bola pemain sepak bola harus memiliki keseimbangan yang baik. Agar pemain itu selalu dapat mempertahankan bola dan posisi tubuhnya saat mendribling bola, meskipun lawan menjegalnya dari depan, samping, maupun dibelakang. Menurut Nurhasan (1986:25) mengemukakan bahwa keseimbangan adalah "kemampuan seseorang mengontrol alat-alat tubuh yang bersifat neuromuscular". Sedangkan Harsono (1988:223) mengemukakan keseimbangan adalah "kemampuan untuk mempertahankan sistem neuromuscular kita dalam kondisi statis, atau mengontrol sistem neuromuscular tersebut dalam posisi efisien selagi kita bergerak". Penyakit neuromuscular memperlihatkan keterlambatan dalam kemampuan berjalan/bergerak atau juga Perkembangan motorik yang lambat.

Dari beberapa pendapat di atas dapat disimpulkan bahwa keseimbangan sangat diperlukan dalam mempertahankan kondisi tubuh, baik dalam keadaan statis (kemampuan mempertahankan keadaan seimbang dalam keadaan diam), maupun dinamis (kemampuan mempertahankan seimbang dalam keadaan bergerak).

Hipotesis Kedua yang diajukan dalam penelitian ini adalah terdapat hubungan yang signifikan (berarti) antara kelincahan dengan hasil dribbling pemain sepakbola SMA Negeri 9 Padang bernilai rhitung $0.477>$ r-tab 0.444 , berarti hubungan kelincahan kuat dan searah (positif). Artinya hipotesis yang diajukan dalam penelitian ini diterima kebenarannya secara empiris. Selanjutnya diperoleh nilai determinasi hasil analisis data (r2) sebesar 0.228. Artinya bahwa kelincahan sebagai independent variabel dapat berkonstribusi sebesar $22.8 \%$ terhadap dependent variabel yaitu hasil dribbling, Sedangkan sisanya diterangkan oleh variabel lain.

Berdasarkan uraian di atas terlihat jelas ketika seorang pemain sepakbola mendribling bola dengan lincah atau gesit pada saat dia berusaha untuk memindahkan bola dari suatu tempat ke tempat lain pada saat permainan berlangsung membutuhkan kelincahan. Jika pemain sepakbola SMA N 9 Padang yang memiliki kelincahan yang baik pasti akan memiliki hasil dribbling yang baik. Dalam arti lain dapat dikatakan bahwa salah satu faktor yang mempengaruhi seorang terampil dalam mendiribling bola adalah kelincahan yang dia miliki, sehingga dengan gesit atau cekatan membawa bola dari suatu tempat ke tempat lain dan terbebas dari rampasan lawan atau bola masih dapat dikontrol dengan baik yang dimiliki seseorang merupakan hasil mengikuti latihan serta keseimbangan tetap terjaga dengan baik.

Hipotesis Ketiga yang di ajukan dalam penelitian ini adalah Terdapat hubungan yang kuat dan searah tetapi tidak signifikan (berarti) antara keseimbangan $\left(\mathrm{X}_{1}\right)$ dan kelincahan $\left(\mathrm{X}_{2}\right)$ secara bersama sama dengan hasil dribbling (Y) pemain sepakbola SMA Negeri 9 Padang bernilai rhitung $0.551>\mathrm{r}$ tab 0.444 Dibuktikan dengan nilai Fhit $3.068>$ Ftab 3.59. Dengan demikian hipotesis kerja yang diajukan (Ha) tidak dapat diterima. Artinya Terdapat hubungan yang kuat dan searah akan tetapi tidak 
Sport Science: Jurnal Sain Olahraga dan Pendidikan Jasmani ISSN 114-562X (Cetak), ISSN XXXX-XXXX(Online)

http://sportscience.ppj.unp.ac.id/index.php/jss/index

signifikan (berarti) antara keseimbangan (X1) dan kelincahan (X2) secara bersama sama dengan hasil dribbling (Y) pemain sepakbola SMA Negeri 9 Padang.

Berpedoman pada temuan penelitian, ternyata variabel keseimbangan (X1) dan kelincahan (X2) secara sendiri-sendiri mempunyai hubungan yang kuat, searah dan signifikan (berarti) dengan hasil dribbling (Y) pemain sepakbola SMA Negeri 9 Padang. Sedangkan variabel keseimbangan (X1) dan kelincahan (X2) secara bersama-sama mempunyai hubungan yang kuat dan searah akan tetapi tidak signifikan (berarti) dengan hasil dribbling (Y) pemain sepakbola SMA Negeri 9 Padang. Artinya mendribling bola yang merupakan suatu usaha dan upaya yang dilakukan pemain sepakbola untuk membawa atau memindahkan bola dari suatu tempat ke tempat lain dengan tujuan untuk melewati lawan, membuka pertahanan lawan dan mengamankan bola dari rampasan lawan, semua gerakan itu menjadi terampil didukung oleh keseimbangan dan kelincahan karena mendribling bola menuntut adanya kegesitan, kecekatan dan bola akan tetap dikuasai sepenuhnya tanpa dapat dirampas oleh lawan.

engan demikian dapat dikatakan keseimbangan dan kelincahan penting artinya bagi seseorang untuk dimiliki, khususnya pada saat melakukan teknik dribbling bola dalam olahraga permainan sepakbola, seperti bagi pemain sepakbola SMA Negeri 9 Padang. Artinya dalam meningkatkan faktor elemen kondisi fisik seperti keseimbangan dan kelincahan dalam bentuk latihan-latihan seperti 1) lari bolak-balik (shuttle run), lari bolak-balik dilakukan secepat mungkin sebanyak 6-8 kali dalam jarak 45 meter. Setiap kali sampai pada satu titik sebagai batas, Si pelaku harus secepatnya berusaha merubah arah untuk berlari menuju titik lainnya. Dalam latihan ini yang diperhatikan ialah keterampilan merubah arah dengan cepat pada waktu bergerak. 2) Lari zig-zag, si pelaku berlari bolak-balik dengan cepat sebanyak 2-3 kali di antara 4-5 titik. Jarak tiap titik 1.5 meter. 3) jongkok-berdiri (squat-thrust).

\section{KESIMPULAN}

Berdasarkan dari hasil penelitian yang telah peneliti uraikan dapat disimpulkan terdapat hubungan signifikan (berarti) antara keseimbangan dengan hasil dribbling pemain sepakbola SMA Negeri 9 Padang bernilai rhitung - $0.451>r_{-t a b} 0.444$, berarti hubungan keseimbangan kuat dan tidak searah (negatif). Dengan demikian hipotesis kerja yang diajukan (Ha) dapat diterima.

Terdapat hubungan yang signifikan (berarti) antara kelincahan dengan hasil dribbling pemain sepakbola SMA Negeri 9 Padang bernilai rhitung $0.477>$ r-tab 0.444, berarti hubungan kelincahan kuat dan searah (positif). Dengan demikian hipotesis kerja yang diajukan (Ha) dapat diterima. Sedangkan Terdapat hubungan yang kuat dan searah tetapi tidak signifikan (berarti) antara keseimbangan dan kelincahan secara bersama sama dengan hasil dribbling pemain sepakbola SMA Negeri 9 Padang bernilai rhitung $0.551>$ r-tab 0.444 Dibuktikan dengan nilai Fhit $3.068>$ Ftab 3.59. Dengan demikian hipotesis kerja yang diajukan (Ha) tidak dapat diterima.

Selanjutnya berdasarkan kesimpulan, maka peneliti dapat memberikan saran-saran pelatih sepakbola agar lebih meningkatkan kreatifitas pemain sepakbola dalam berlatih, sehingga keterampilan dribbling bola pemain sepakbola dapat ditingkatkan. Pemain agar membiasakan diri dalam beraktivitas latihan-latihan fisik yang dapat meningkatkan kemampuan kondisi fisik, keseimbangan dan kelincahan agar keterampilan teknik dapat ditingkatkan. Orang tua atau wali murid agar memperhatikan kecukupan atau kebutuhan gizi anaknya, karena hal ini berpengaruh terhadap kondisi fisik mereka.

\section{DAFTAR RUJUKAN}

Arikunto.1997. Manajemen Peneltian. Jakarta: P2LPTK

Asnaldi, A. (2016). Hubungan Pendekatan Latihan Massed Practice Dan Distributed Practice

Terhadap Ketepatan Pukulan Lob Pemain Bulutangkis. Jurnal MensSana. 
https://doi.org/https://doi.org/10.24036/jm.v1i2.51

Asnaldi, A. (2019). Kontribusi Motor Ability Dan Konsentrasi Terhadap Kemampuan Penguasaan Kata Heian Yodan Karateka Lemkari Dojo Angkasa Lanud Padang. Jurnal Menssana, 4(1), 17. https://doi.org/10.24036/jm.v4i1.30

Arsil. 2006. Tes Pengukuran dan Jasmani Untuk Sekolah Dasar. Jakarta: Dipus Diklat Olahraga Pelajar.

Depdikbud.1992.Paket Penelitian dan Kesegaran Jasmani Dan Kesehatan Rekreasi. Jakarta Pusat Diklat Olahraga Pelajar.

Harsono.1988.Choacing dan Aspek-Aspek Psikologi Dalam Choacing. Jakarta:P2LPTK

Luthan.1991. Manusia Dan Olahraga. Bandung: ITB dan FPOK IKIP Bandunng

Nurhasan.1999.Tes Pengukuran Dalam Pendidikan Jasmani: Prinsip-Prinsip dan Penerapannya. Depdiknas:Dirjen Pendidikan Dasar dan Menengah.

Ridwan.2005. Belajar Mudah Penelitian Untuk Guru, Karyawan dan Penelitian Pemula. Bnadung: Alfabeta.

Rosmawati. (2016). Hubungan Daya Ledak Otot Tungkai Dengan Kemampuan Shooting Pemain Club Futsal Sekolah Menengah Kejuruan Nusatama Padang. Jurnal MensSana, 1(2), 11-19. https://doi.org/https://doi.org/10.24036/jm.v1i2.49

Velnika Elmanisar, Yulifri, A. S. (2017). Hubungan Kelincahan dengan Kecepatan Dribbling dalam Pengembangan Diri Cabang Sepakbola. Jurnal Sport Science, 17(1), 36-47. https://doi.org/https://doi.org/10.24036/jss.v17i1.6

Zalfendi,Dkk.2010.BukuAjarSepakbola.Padang.FIK-UNP 